\title{
Nexus between Corporate Governance and Financial Performance: Corroboration from Indian Banks
}

\author{
Sanjeeb Kumar Dey , Debabrata Sharma
}

Department of Commerce, Ravenshaw University, Odisha-753003, India

Received September 21, 2020; Revised November 17, 2020; Accepted November 29, 2020

\section{Cite This Paper in the following Citation Styles}

(a): [1] Sanjeeb Kumar Dey, Debabrata Sharma, "Nexus between Corporate Governance and Financial Performance: Corroboration from Indian Banks, "Universal Journal of Accounting and Finance, Vol. 8, No. 4, pp. 140 - 147, 2020. DOI: 10.13189/ujaf.2020.080406.

(b): Sanjeeb Kumar Dey, Debabrata Sharma (2020). Nexus between Corporate Governance and Financial Performance: Corroboration from Indian Banks. Universal Journal of Accounting and Finance, 8(4), 140 - 147. DOI: 10.13189/ujaf.2020.080406.

Copyright $\odot 2020$ by authors, all rights reserved. Authors agree that this article remains permanently open access under the terms of the Creative Commons Attribution License 4.0 International License

\begin{abstract}
Corporate governance (CG) is now a world phenomenon and the nucleus of economic regulations. History evidenced that failure in corporate governance might lead to economic turmoil. Governance of banks is particularly important for a country like India which is still in the path of economic development. In this paper, we have tried to establish the nexus between corporate governance practices and financial performance of selected Indian public sector banks. The study is empirical in nature and is based on secondary data collected from CMIE Prowess database. We have considered ten public sector banks based on their balance sheet size covering seven years ending on 2019. We have used Correlation and Regression Model to achieve our objectives. Two performance variables, eight corporate governance variables and two control variables have been used for this purpose. Based on the diagnostic tests, we applied fixed effects generalised least square (GLS) regression. Our results showed that financial performance (ROA and ROE) is negatively associated with board size, board meetings, board committees and board independence. On the contrary, we found a positive relationship between the number of woman directors, executive directors, non-executive directors and banks' performance measures. Finally, we suggest that public sector banks should not have a board size beyond a certain limit. Our study will provide a new dimension to the existing literatures regarding the impact of governance and banking sector in particular.
\end{abstract}

Keywords Corporate Governance, Bank, India,
Performance, ROA, ROE

\section{Introduction}

Over the last three decades, the Indian economy as well as the global economy have been in turmoil because of the unforeseen catastrophes of big corporate houses. For these failures, the men in charge of the company have always been responsible. It is because of the misconduct or frauds of some people at the top level that some of the prominent companies have met with sudden downfall. These failures have rose a question the answer of which is not yet clear; "who will guard the guards?" During the said period, there have been a number of governance scandals which displayed lack of ethical corporate behaviour. In India, some of the reputed companies like Satyam, Kingfisher Airlines, PNB, and Sahara India etc. have failed shockingly only because of their corporate misconduct and fraudulent practices. The global economy has also seen tragic failures of some of the renowned companies like Enron, WorldCom, Bank of Credit and Commerce International (BCCI) etc. Because of these corporate failures, corporate governance has been successful in captivating economic deliberations and global concern. Corporate governance has been accepted as one of the most essential factors for economic growth and stability. Among all the industries, governance of the banking industry is of paramount importance as governance 
failures of banks not only hamper economic growth, it also forces economic slowdown. Banks collect deposits from inaccessible stakeholders and utilise them for economic growth. The presence of dispersed stakeholders in enormous numbers make the banks different from other corporates.

Corporate governance has attracted the attention of not only economists and governments but also academicians and researchers as well. There have been a growing number of studies on the impact of corporate governance on the performance of companies. In India, however, the surge in corporate governance research has come only during the last decade. The mandatory regulations, listing agreements, improving governance norms have contributed towards the growth of governance research in India. Corporate governance is a process through which suppliers of capital assure themselves about getting some return on their investment. The need for corporate governance will always be there till ownership and management are segregated. Shareholders are the owners who delegate the authority of managing the business to the managers. The basic objective of managers is to protect the interest of shareholders and corporate governance brings alignment between the interests of owners and managers. Protecting the interests of all stakeholders is the basic objective of corporate governance. As per the views of John and Senbet [12] "corporate governance deals with mechanisms by which stakeholders of a corporation exercise control over corporate insiders and management such that their interests are protected". A growing number of empirical studies have focused on the impact of corporate governance on firm performance. Prior research also indicates that corporate financial performance is immediately affected if there is a decrease in the effectiveness of corporate governance. Board of directors and CEO are one of the important mechanisms of the corporate governance structure. In the words of Kathuria and Dash [14], performance of the company is, to a large extent, affected by the prevalent board culture in the corporation. Kumar and Singh [16] says that corporate governance relies much on internal structures rather than external ones for enhancing the firm value.

In the present study, we analyse the impact of board related variables of corporate governance on the financial performance of Indian public sector banks. We have selected seven corporate governance parameters and two performance measures for our analysis.

\section{Theoretical Background \& Hypothesis Development:}

Before going to the analysis stage, we briefly review the prior research conducted for examining the impact of corporate governance characteristics on firms' performance. As per the agency theory, board of directors are the first corporate governance mechanism which represent and protect owners' interests. It is the duty of the board of directors to ensure that managers achieve organisational goals. Bhimani [6] writes that an established board with sufficient number of directors should be able to monitor the management effectively. Kumar and Singh [16] also proposes that board size is an important attribute that affects performance of firms. Apart from board size, there are some other corporate governance mechanisms which may also affect firm performance like board meeting frequency, number of board committees, presence of woman director on the board, number of independent directors, executive and non-executive directors on the board, board independence, and board composition, etc.

Merendino and Melville [18] found a positive effect of small board size on firm performance and vice-versa. They have reported similar results in case of board independence as a lower board independence has shown positive impact on performance of firms. In another study, Borlea et al. [7] found no statistically significant association between board characteristics and firm performance. While some studies have found positive association between board size and financial performance (Dwivedi and Jain [8], Kathuria and Dash [14]), other authors have also reported a negative association (Ghosh [11], Kumar and Singh [16]). In another study, Abdul Gafoor et al. [1] found that board size has significant relationship with performance of banks and board independence has a significant positive relationship with bank performance. Board size and board independence have also been used in a number of studies in relation to banks' performance. (Adams and Mehran [2], Aebi et al. [3], Andres and Vallelado [5], Erkens et al. [9], Faleye and Krishnan [10], Liang et al. [17], Sarkar and Sarkar [20]). In a study conducted on the listed companies of Pakistan, Singh et al. [21] reported a positive effect of board size on the performance measure. They also reported a negative impact of board independence. Using the sample of 17 banks of UK, Tanna et al. [22] found a positive association between board size and efficiency of banks. Waheed and Ali Malik [23] concluded that a larger board size benefits the organisation and independent directors negatively affects the financial performance of Pakistani companies. The study conducted by Zhou et al. [24] reported that companies listed in Athens Stock Exchange with a lager board size performed better and firms with more independent directors performed badly. The literatures on board variables suggest that there are not many studies available in Indian context in general and the Indian banking sector in particular. Therefore, we propose our first two hypotheses in the null format as follows;

H1: Board size negatively affects banks' performance.

H2: Board independence positively affects banks' performance. 
The frequency of board meetings is another important mechanism found in corporate governance literature. Board meetings are the reason for all directors to be together and for making suitable decisions for the organisation. In this context, Ajanthan et al. [4] pointed out that board meeting frequency has a positive relationship with performance of state banks in Sri Lanka. Active participation in board meetings helps the directors on board in efficiently discharging their responsibilities of monitoring and providing resource linkages (Mishra and Kapil [19]). Board of directors show their commitment towards the organisation by actively participating in board meetings. Mishra and Kapil [19] have found that the number of board meetings is significantly and positively related to firm performance measured with the help of Tobin's Q.

H3: Number of board meetings positively affects performance of Indian banks.

Companies form different types of committees as per the regulatory requirements and to deal with specific matters effectively and efficiently. Banks, on the other hand, form more board level committees as they have to deal with a variety of matters. It is generally perceived that forming different committees for specific matters will improve banks' performance and value. In this context, Kiranmai and Mishra [15] reported that board committees have no significant impact on performance of state owned enterprises. We define the null hypothesis for board committees in the following manner.

H4: Number of board level committees positively affects performance of Indian banks.

There has been a growing debate regarding inclusion of woman directors on the board. In India, the law mandates that companies should have at least one woman director on the board. It is perceived that woman directors create firm value. In a recent study, Kiranmai and Mishra [15] found that woman directors have a negative and significant impact on firm performance (net profit) of state-owned enterprises in India. However, there have not been many studies on the direct effect of woman directors on firm performance. Executive directors (EDs) take part in the day to day business affairs of the organisation. On the other hand, non-executive directors (NEDs) are not engaged in the routine management process but they are involved in planning and policy making. One of the important responsibilities of NEDs is that they monitor the activities of EDs and acts in the best interest of stakeholders. In case of a financial institution, the presence and role of NEDs are crucial as banks possess diverse and geographically dispersed stakeholders. Non-executive directors can no longer be used for window dressing purposes only and are considered as a safeguard and a significant source of economic and competitive advantage (Kakabadse et al. [13]).

H5: There is a positive impact of number of woman directors on banks' performance.

H6: Number of executive directors positively affects banks' performance.

H7: Number of non-executive directors is positively related with banks' performance.

\section{Research Methodology}

We use ten Indian public sector banks as our sample size in this study. The banks have been chosen on the basis of their total asset size as on $31^{\text {st }}$ March, 2019. The sample banks are State Bank of India, Punjab National Bank, Bank of Baroda, Bank of India, Canara Bank, Union Bank of India, Industrial Development Bank of India, Central Bank, Syndicate Bank, and Oriental Bank of Commerce. The sample period is seven years from 2013 to 2019. Data of corporate governance variables have been collected form the annual reports of the respective banks and the data representing financial performance have been collected from CMIE Prowess database. We have also used some control variables in the regression model referring to previous studies.

\subsection{Variable Measurement:}

\subsubsection{Performance variables}

The existing literature on corporate governance suggests different measures for measuring performance of firms. In this paper, we selected two accounting-based measures ROA (Return on Assets) and ROE (Return on Equity) as performance parameters on the basis of prior studies (Abdul Gafoor et al. [1], Borlea et al. [7], Sarkar and Sarkar [20]).

\subsubsection{Governance variables}

In the present paper, we used the corporate governance measures board size (BS), board meetings (BM), board committees (BC), woman director (WD), executive director (ED), non-executive director (NED) and board independence (BIND) as board attributes. These attributes have been used as predictor variables in the regression to find out the impact on performance of selected banks.

\subsubsection{Control variables}

Control variables have been a part of analysis in many previous corporate governance studies. These variables have also shown relation with firm performance in prior literatures (Kumar and Singh [16], Merendino and Melville [18]). Based on the literature surveyed, we used firm age and firm size as control variables in our study (Abdul Gafoor et al. [1], Kumar and Singh [16], Sarkar and Sarkar [20]) (refer table 1).

\subsubsection{Regression Model}

The model used in our study is expressed with the help of the following equation:

$$
\begin{gathered}
\text { Performance }=\beta 0+\beta 1 B S+\beta 2 B M+\beta 3 B C+\beta 4 W D+ \\
\beta 5 E D+\beta 6 N E D+\beta 7 B I N D+\beta 8 \text { Age }+\beta 9 \text { Size }+\varepsilon
\end{gathered}
$$


Table 1. Definition and Measurement of Variables

\begin{tabular}{|c|c|c|c|}
\hline Variable & Type & Definition and Measurement & Source \\
\hline ROA & $\begin{array}{l}\text { Dependent - } \\
\text { Performance }\end{array}$ & Ratio of net profit to total assets. & Prowess \\
\hline ROE & $\begin{array}{l}\text { Dependent - } \\
\text { Performance }\end{array}$ & Ratio of net profit to shareholders' equity. & Prowess \\
\hline BS & $\begin{array}{l}\text { Independent - } \\
\text { Governance }\end{array}$ & Total number of directors on the board. & Annual Report \\
\hline BM & $\begin{array}{l}\text { Independent - } \\
\text { Governance }\end{array}$ & Number of board meetings conducted. & Annual Report \\
\hline BC & $\begin{array}{l}\text { Independent - } \\
\text { Governance }\end{array}$ & Number of board level committees. & Annual Report \\
\hline WD & $\begin{array}{l}\text { Independent - } \\
\text { Governance }\end{array}$ & Number of woman directors on the board. & Annual Report \\
\hline ED & $\begin{array}{l}\text { Independent - } \\
\text { Governance }\end{array}$ & Number of executive directors on the board. & Annual Report \\
\hline NED & $\begin{array}{l}\text { Independent - } \\
\text { Governance }\end{array}$ & Number of non-executive directors on the board. & Annual Report \\
\hline BIND & $\begin{array}{l}\text { Independent - } \\
\text { Governance }\end{array}$ & Ratio of independent directors to total directors. & Annual Report \\
\hline Age & Independent - Control & Natural logarithm of current age of a bank. & Annual Report \\
\hline Size & Independent - Control & Natural logarithm of bank's total assets & Annual Report \\
\hline
\end{tabular}

Table 2. Summary Statistics

\begin{tabular}{|c|c|c|c|c|c|}
\hline & Minimum & Maximum & Mean & Median & Std. Deviation \\
\hline BS & 7 & 17 & 11.21 & 11 & 2.28 \\
\hline BM & 5 & 21 & 14.43 & 14.50 & 2.89 \\
\hline BC & 4 & 22 & 15.21 & 15 & 4.60 \\
\hline WD & 0 & 3 & 1.07 & 1 & 0.75 \\
\hline ED & 1 & 5 & 3.06 & 3 & 1.01 \\
\hline NED & 0 & 12 & 6.00 & 6.50 & 0.10 \\
\hline BIND & 0.00 & 0.79 & 0.35 & 0.28 & 0.21 \\
\hline ROA & -4.68 & 1.01 & -0.11 & 0.21 & 22.22 \\
\hline ROE & -66.73 & 23.48 & -7.39 & 0.67 & 0.66 \\
\hline Age & 2.20 & 4.83 & 4.31 & 4.58 & 0.65 \\
\hline Size & 21.42 & 24.33 & 22.33 & 22.26 & \\
\hline
\end{tabular}

(Source: Authors' Calculation)

\section{Results and Discussions}

\subsection{Summary Statistics}

Our analysis begins with the calculation of descriptive statistics of the variables. Table 2 shows the descriptive statistics of variables used in the study. Board size of top ten Indian public sector banks ranges from 7 to 17 directors with 11.21 (11) being mean (median). The present sample appears to have a larger board size than the prescribed limit for Indian banks. The average number of woman directors, executive directors and non-executive directors sitting on the boards is 1,3 and 6 respectively. The independent directors represent $35 \%$ of the board on average.

\subsection{Correlation Analysis}

Table 3 shows the bivariate Pearson correlation between all the variables used in the study. The correlation analysis shows that ROA is significantly and positively related with board size (at 5\%) and number of non-executive directors (at $1 \%$ ). It also showed a significant but negative correlation with board committees at $5 \%$ level of significance. This implies that increase in the board size and the number of non-executive directors on the board enables the banks to get more return on assets. ROE, on the other hand, showed a significant and positive relation with board size and non-executive directors at $1 \%$ level of significance. ROE also showed the same results in case of board committees. 
Table 3. Correlation Matrix

\begin{tabular}{|c|c|c|c|c|c|c|c|c|c|}
\hline & BS & BM & BC & WD & ED & NED & BIND & Age & Size \\
\hline BS & 1 & & & & & & & & \\
\hline BM & 0.026 & 1 & & & & & & & \\
\hline BC & -0.205 & 0.186 & 1 & & & & & & \\
\hline WD & 0.186 & -0.021 & -0.194 & 1 & & & & & \\
\hline ED & $.488^{* *}$ & 0.021 & -0.203 & 0.129 & 1 & & & & \\
\hline NED & $.676^{* *}$ & 0.012 & 0.155 & -0.050 & 0.233 & 1 & & & \\
\hline BIND & 0.010 & $-.336^{* *}$ & -0.144 & 0.044 & -0.120 & 0.066 & 1 & & \\
\hline Age & 0.190 & 0.228 & 0.062 & 0.088 & 0.104 & $.283^{*}$ & -0.201 & & 1 \\
\hline Size & $.338^{* *}$ & 0.028 & $-.305^{*}$ & 0.222 & $.815^{* *}$ & 0.214 & -0.185 & 0.118 & 1 \\
\hline
\end{tabular}

(Source: Authors' Calculation)

Note: **significant at $1 \%$ level *significant at $5 \%$ level

\subsection{Econometric Analysis}

In the present study, we are dealing with panel data and before applying a suitable regression model we have to account for multicollinearity. The problem of multicollinearity is said to exist when there is high correlation between two or more independent variables and in that case it becomes difficult to establish the effect of each on the performance measures. To check for multicollinearity, we calculated variance inflation factor (VIF) and tolerance. The results, as shown in Table 4, indicate that there is no problem of multicollinearity in our data as none of variables have a VIF more than 10 . The average value of VIF is 2.37 . The tolerance value close to one indicates no multicollinearity and the same is found from the results reported in table 4 .

Table 4. Collinearity Statistics

\begin{tabular}{|c|c|c|}
\hline Variable & VIF & Tolerance (1/VIF) \\
\hline BS & 3.42 & 0.293 \\
\hline BM & 1.14 & 0.878 \\
\hline BC & 1.70 & 0.589 \\
\hline WD & 1.27 & 0.789 \\
\hline ED & 4.18 & 0.239 \\
\hline NED & 2.95 & 0.339 \\
\hline BIND & 1.37 & 0.727 \\
\hline Age & 1.29 & 0.776 \\
\hline Size & 4.03 & 0.248 \\
\hline Mean VIF & 2.37 & \\
\hline
\end{tabular}

(Source: Authors' calculation)

To achieve the objectives of our study, we implemented ordinary least square (OLS) estimators. But, OLS estimator is suitable only when its assumptions are fulfilled. To check whether OLS model will be used or not, we accounted for serial correlation among the data by applying Wooldridge test for autocorrelation and heteroscedasticity by using the Breusch-Pagan test. The results of both these tests are presented in table 5 . The null hypothesis of the Wooldridge test is that there is no first order autocorrelation and as per table 5, we failed to reject the null hypothesis indicating that there is no autocorrelation in any model. On the other hand, the null hypothesis for the Breusch-Pagan test is that there is constant variance i.e. no heteroskedasticity in the data. We rejected the null hypothesis for both the models which suggests that there is heteroskedasticity in the data.

Table 5. Diagnostic tests

\begin{tabular}{|c|c|c|c|c|}
\hline \multirow{2}{*}{$\begin{array}{c}\text { Model } \\
\text { with } \\
\text { Dependent } \\
\text { Variable }\end{array}$} & \multicolumn{2}{|c|}{$\begin{array}{c}\text { Wooldridge } \\
\text { test for } \\
\text { autocorrelation }\end{array}$} & \multicolumn{2}{|c|}{$\begin{array}{c}\text { Breusch-Pagan/Cook-Weisberg } \\
\text { test for heteroscedasticity }\end{array}$} \\
\cline { 2 - 5 } & $\begin{array}{c}\mathrm{F} \\
\text { value }\end{array}$ & p-value & Chi-square & p-value \\
\hline ROA & 0.158 & 0.7004 & $17.86^{* * *}$ & 0.0000 \\
\hline ROE & 0.001 & 0.9721 & $5.70^{* *}$ & 0.0169 \\
\hline
\end{tabular}

(Source: Authors' calculation)

Note: Statistically significant at $1 \%$ level $(* * *), 5 \%$ level $(* *), 10 \%$ level (*).

To apply OLS model, both assumptions regarding serial correlation and heteroskedasticity should be satisfied. However, we found heteroskedasticity in our data and therefore we are going to use GLS panel data regression models which includes fixed effects and random effects model. GLS model is preferable when there is a chance of certain degree of correlation among the variables and there are unequal variances in the observations. We used Hausman Specification test to select the better model among fixed effects and random effects. The null hypothesis for Hausman test is that the random effects model is more appropriate than the fixed effects model. As reported in Table 6, the Hausman test revealed a significant result which resulted in rejecting the null hypothesis for both dependent variables. Therefore, we applied the fixed effects model in our study. However, we also reported the outputs of the OLS estimators to observe the difference between the two models. 
Table 6. Hausman Specification Test

\begin{tabular}{|c|c|c|c|}
\hline $\begin{array}{c}\text { Model with } \\
\text { Dependent } \\
\text { Variable }\end{array}$ & $\begin{array}{c}\text { Chi-square } \\
\text { statistics }\end{array}$ & $\begin{array}{c}\text { Degree of } \\
\text { Freedom }\end{array}$ & p-value \\
\hline ROA & $66.29^{* * *}$ & 9 & 0.0000 \\
\hline ROE & $23.27^{* * *}$ & 9 & 0.0056 \\
\hline
\end{tabular}

(Source: Authors' calculation)

Note: Statistically significant at $1 \%$ level $(* * *), 5 \%$ level $(* *), 10 \%$ level $(*)$.

As suggested by the Hausman test, we applied the fixed effects model for both performance measures. Table 7 and table 8 depicts the results of fixed effects regression with coefficients and t-values. In our study, we hypothesized a negative impact of board size on financial performance. Consistent with past studies, we also found a negative association between board size (H1) and performance measures ROA and ROE (though not statistically significant) as reflected by the negative coefficients in both the models. In relation to $\mathrm{H} 2$ and $\mathrm{H} 3$, we did not find any significant results and therefore failed to reject the null hypothesis of board independence and board meetings in case of both performance measures. So, we conclude that board independence and board meetings have no significant impact on the performance of selected banks.

Table 7. Regression of ROA with Governance Variables

\begin{tabular}{|c|c|c|c|c|}
\hline \multirow{2}{*}{} & \multicolumn{2}{|c|}{ OLS } & \multicolumn{2}{c|}{ GLS (FE) } \\
\cline { 2 - 5 } & Coefficients & t-statistics & Coefficients & t-statistics \\
\hline BS & -0.101 & -1.23 & -0.054 & -0.76 \\
\hline BM & -0.066 & $-1.75^{*}$ & -0.032 & -1.04 \\
\hline BC & -0.103 & $-3.59^{* * *}$ & -0.078 & $-1.90^{*}$ \\
\hline WD & 0.030 & 0.20 & 0.084 & 0.65 \\
\hline ED & 0.047 & 0.23 & 0.169 & 0.92 \\
\hline NED & 0.186 & $3.31^{* * *}$ & 0.052 & 0.91 \\
\hline BIND & -0.887 & -1.57 & -0.245 & -0.34 \\
\hline Age & 0.214 & 1.23 & -9.438 & $-6.51^{* * *}$ \\
\hline Size & -0.201 & -0.64 & -0.744 & -1.04 \\
\hline cons & 6.103 & 0.88 & 57.684 & $3.56^{* * *}$ \\
\hline $\begin{array}{c}\text { F } \\
\text { statistics }\end{array}$ & \multicolumn{2}{|c|}{$3.96^{* * *}$} & \multicolumn{2}{c|}{$8.48^{* * *}$} \\
\hline$R^{2}$ & \multicolumn{2}{|c|}{0.3725} & \multicolumn{2}{c|}{0.7496} \\
\hline $\begin{array}{c}\text { Adjusted } \\
R^{2}\end{array}$ & \multicolumn{2}{|c|}{0.2783} & \multicolumn{2}{c|}{0.6612} \\
\hline
\end{tabular}

(Source: Authors' calculation). Significant at $1 \%$ level (***), 5\% level $(* *), 10 \%$ level $(*)$

We did find negative relationship of board independence and board meetings with both ROA and ROE which contradicted our prediction. We rejected the null hypothesis of board committees (H4) only in case of ROA which indicates that board committees have significant impact on banks' performance. However, it did not have any significant impact ROE of banks. With respect to woman directors (H5), executive directors (H6) and non-executive directors (H7), we rejected the null hypothesis relating to both performance measures. These three board variables have no significant impact on performance of selected Indian banks though we find a positive association between these governance parameters and performance measures. The R-squared values indicate that corporate governance variables are responsible for $74.96 \%$ variation in ROA and $66.30 \%$ variation in ROE. The regression models have significant $F$ values suggesting that the models are good in explaining the relationship.

Table 8. Regression of ROE with Governance Variables

\begin{tabular}{|c|c|c|c|c|}
\hline \multirow{2}{*}{} & \multicolumn{2}{|c|}{ OLS } & \multicolumn{2}{c|}{ GLS (FE) } \\
\cline { 2 - 5 } & Coefficients & t-statistics & Coefficients & t-statistics \\
\hline BS & -2.10 & -1.15 & -0.249 & -0.14 \\
\hline BM & -1.144 & -1.38 & -0.626 & -0.80 \\
\hline BC & -2.559 & $-4.02^{* * *}$ & -1.688 & -1.59 \\
\hline WD & 0.217 & 0.06 & 0.492 & 0.15 \\
\hline ED & 2.50 & 0.55 & 2.996 & 0.63 \\
\hline NED & 4.545 & $3.65^{* * *}$ & 1.425 & 0.96 \\
\hline BIND & -10.389 & -0.83 & -15.534 & -0.83 \\
\hline Age & 1.615 & 0.42 & -173.788 & $-4.61^{* * *}$ \\
\hline Size & -8.170 & -1.18 & -24.788 & -1.34 \\
\hline cons & 215.36 & 1.40 & 1315.484 & $3.13^{* * *}$ \\
\hline $\begin{array}{c}\text { F } \\
\text { statistics }\end{array}$ & \multicolumn{2}{|c|}{$4.19^{* * *}$} & \multicolumn{2}{c|}{$5.57^{* * *}$} \\
\hline $\mathrm{R}^{2}$ & \multicolumn{2}{|c|}{0.3858} & \multicolumn{2}{c|}{0.6630} \\
\hline $\begin{array}{c}\text { Adjusted } \\
\mathrm{R}^{2}\end{array}$ & \multicolumn{2}{|c|}{0.2937} & \multicolumn{2}{c|}{0.5441} \\
\hline
\end{tabular}

(Source: Authors' calculation). Significant at $1 \%$ level $(* * *), 5 \%$ level $(* *), 10 \%$ level $(*)$.

Among the two control variables used in the study, age of the banks found to be statistically significant at $1 \%$ level for both ROA and ROE. This indicates that the age of public sector banks have significant impact on their performance. Size of the banks did not show any significant results with the performance measures. Therefore, we conclude that increasing the total assets didn't improve the financial performance of banks. We found negative coefficients of age and size of the banks in both models, suggesting that with the increase in age and total assets of public sector banks during the last seven years (2013-2019) have not contributed to the growth of their returns on assets and equity.

\section{Conclusions}

The study assessed the nexus between corporate governance and financial performance of selected Indian public sector banks. Board size found to be negatively associated with both performance parameters ROA and ROE which is in line with the findings of previous Indian 
studies (Ghosh [11], Kumar and Singh [16]). Board meetings, board committees and board independence are found to be negatively associated with the banks' performance (Sarkar and Sarkar [20]). Number of executive and non-executive directors found to be positively associated with both ROA and ROE though the relation was not statistically significant. Woman directors did show a positive relation with ROA and ROE and both relations were not significant. Our findings showed a statically significant and negative association between age and financial performance of banks.

We conclude that since most of the sample banks have a large board size, banks may not be able to take significant business decisions. There may be lack of coordination and communication among the directors which affected the banks' performance. Few sample banks did not have the minimum number of independent directors which may be affecting their performance in the long-run and the overall results of the study. Our paper contributes to the existing literature on corporate governance relating to the seven board characteristics.

\section{Limitations and Future Directions}

Our research and its conclusions are subject to few limitations. The first being use of a small sample of 10 Indian public sector banks. Second, we couldn't include other board related corporate governance measures which may have some effect on banks' performance like directors' ownership, directors' busyness, promoters' ownership etc.

The current study also provides some directions for future research. We suggest a longitudinal analysis including other governance parameters like ratio of non-executive directors, share ownership of directors' and promoters' etc. which may have an effect on board structure. Lastly, future studies can also be conducted using primary data which can provide better understanding about the relationship between corporate governance and firm performance.

\section{REFERENCES}

[1] Abdul Gafoor C P., Mariappan V., Thyagarajan S., "Board Characteristics and Bank Performance in India," IIMB Management Review, vol. 30, no. 2, pp. 160-167, 2018. DOI: $10.1016 /$ j.iimb.2018.01.007

[2] Adams R B., Mehran H., "Bank Board Structure and Performance: Evidence for Large Bank Holding Companies," Journal of Financial Intermediation, vol. 21, no. 2, pp. 243-267, 2012. DOI: 10.1016/j.jfi.2011.09.002

[3] Aebi V., Sabato G., Schmid M., "Risk Management, Corporate Governance, and Bank Performance in the Financial Crisis," Journal of Banking and Finance, vol. 36, no. 12 , pp. $3213-3226$, 2012. DOI: 10.1016/j.jbankfin. 2011 .10 .020

[4] Ajanthan A., Balaputhira S., Nimalathashan B., "Corporate Governance and Banking Performance: A Comparative Study between Private and State Banking Sector in Sri Lanka," European Journal of Business and Management, vol. 5, no. 20, pp. 92-100, 2013.

[5] Andres P de., Vallelado E., "Corporate Governance in Banking: The Role of the Board of Directors," Journal of Banking and Finance, vol. 32, no. 12, pp. 2570-2580, 2008. DOI: $10.1016 /$ j.jbankfin.2008.05.008

[6] Bhimani A., "Risk Management, Corporate Governance and Management Accounting: Emerging Interdependencies," Management Accounting Research, vol. 20, no. 1, pp. 2-5, 2009. DOI: 10.1016/j.mar.2008.11.002

[7] Borlea S N., Achim M V., Mare C., "Board Characteristics and Firm Performances in Emerging Economies. Lessons from Romania. Economic Research-Ekonomska Istrazivanj a, vol. 30, no. 1, pp. 55-75, 2017. DOI: 10.1080/1331677X.2017.1291359

[8] Dwivedi N., Jain A K., "Corporate Governance and Performance of Indian Firms: The Effect of Board Size and Ownership," Employee Responsibilities and Rights Journal, vol. 17, no. 3, pp. 161-172, 2005. DOI: 10.1007/s10672-005-6939-5

[9] Erkens D H., Hung M., Matos P., "Corporate Governance in the 2007-2008 Financial Crisis: Evidence from Financial Institutions Worldwide," Journal of Corporate Finance, vol. 18, no. 2, pp. 389-411, 2012. DOI: 10.1016/j.jcorpfin.2012. 01.005

[10] Faleye O., Krishnan K. "Risky Lending: Does Bank Corporate Governance Matter?" Journal of Banking and Finance, vol. 83, pp. 57-69, 2017. DOI: 10.1016/j.jbankfin. 2017.06.011

[11] Ghosh S., "Do Board Characteristics Affect Corporate Performance? Firm-level Evidence for India," Applied Economics Letters, vol. 13, no. 7, pp. 435-443, 2006. DOI: $10.1080 / 13504850500398617$

[12] John K., Senbet L W., "Corporate Governance and Board Effectiveness," Journal of Banking \& Finance vol. 22, pp. 371-403, 1998. DOI: 10.1016/S0378-4266(98)00005-3

[13] Kakabadse A., Ward K., Korac-kakabadse N., Bowman C., "Role and Contribution of Non-executive Directors," Corporate Governance: The International Journal of Business in Society, vol. 1, no. 1, pp. 4-8, 2006. DOI: 10.1108/EUM0000000005455

[14] Kathuria V., Dash S., "Board Size and Corporate Financial Performance: An Investigation," Vikalpa, vol. 24, no. 3, pp. 11-17, 1999. DOI: 10.1177/0256090919990303

[15] Kiranmai J., Mishra R K. "Corporate Governance Practices in Listed State-owned Enterprises in India: An Empirical Research," Indian Journal of Corporate Governance, vol. 12, no. 1, pp. 94-121, 2019. DOI: 10.1177/0974686219849760

[16] Kumar N., Singh J P., "Effect of Board Size and Promoter Ownership on Firm Value: Some Empirical Findings from India," Corporate Governance, vol. 13, no. 1, pp. 88-98, 2013. DOI: $10.1108 / 14720701311302431$ 
[17] Liang Q., Xu P., Jiraporn P., Board Characteristics and Chinese Bank Performance," Journal of Banking and Finance, vol. 37, no. 8, pp. 2953-2968, 2013. DOI: 10.1016/j.jbankfin.2013.04.018

[18] Merendino A., Melville R., "The Board of Directors and Firm Performance: Empirical Evidence from Listed Companies," Corporate Governance: The International Journal of Business in Society, vol. 19, no. 3, pp. 508-551, 2019. DOI: $10.1108 / \mathrm{CG}-06-2018-0211$

[19] Mishra R K., Kapil S., "Board Characteristics and Firm Value for Indian Companies," Journal of Indian Business Research, vol. 10, no. 1, pp. 2-32, 2018. DOI: 10.1108/JIBR-07-2016-0074

[20] Sarkar J., Sarkar S., "Bank Ownership, Board Characteristics and Performance: Evidence from Commercial Banks in India," International Journal of Financial Studies, vol. 6, no. 1, pp. 17, 2018. DOI: 10.3390/ijfs6010017

[21] Singh S., Tabassum N., Darwish, T. K., Batsakis G.,
"Corporate Governance and Tobin's Q as a Measure of Organizational Performance," British Journal of Management, vol. 29, no. 1, pp. 171-190, 2018. DOI: $10.1111 / 1467-8551.12237$

[22] Tanna S., Pasiouras F., Nnadi M., "The Effect of Board Size and Composition on the Efficiency of UK Banks," International Journal of the Economics of Business, vol. 18, no. 3, pp. 441-462, 2011. DOI: 10.1080/13571516.2011.61 8617

[23] Waheed A., Ali Malik Q., "Board characteristics, ownership concentration and firms' performance," South Asian Journal of Business Studies, vol. 8, no. 2, pp. 146-165, 2019. DOI: 10.1108/SAJBS-03-2018-0031

[24] Zhou H., Owusu-Ansah S., Maggina A., "Board of Directors, Audit Committee, and Firm Performance: Evidence from Greece," Journal of International Accounting, Auditing and Taxation, vol. 31 , pp. 20-36, DOI: 10.1016/j.intaccaudtax.2 018.03 .002 